\title{
PERAN KEPALA SEKOLAH TERHADAP PENINGKATAN KOMPETENSI PROFESIONALITAS GURU PADA PROSES PEMBELAJARAN DI SDN 22 BENGKALIS
}

\author{
Ali Anas \\ SDN 22 Bengkalis, Riau, Indonesia \\ pakalianasbks@gmail.com
}

\begin{abstract}
ABSTRAK
penelitian ini merupakan tindakan sekolah yang bertujuan untuk meningkatkan mutu sekolah dan memperbaiki kinerja guru. Penelitian ini dilakukan di SDN 22 X, subjek dalam penelitian ini adalah guru-guru yang mengajar di Sekolah tersebut. Metode penelitian ini menggunakan metode kuantitatif deskriptif yang menjelaskan dan menggambarkan secara nyata fakta-fakta yang ditemukan pada saat penelitian. Tujuan utama dalam penelitian ini yaitu untuk meningkatkan serta mengembangkan kemampuan atau kompetensi profesionalitas guru dalam pembelajaran sehingga tercipta kondisi belajar yang baik dan menghasilkan hasil belajar yang baik sehingga dapat meningkatkan mutu pendidikan. Berdasarkan dari hasil penelitian dapat dilihat bahwa peran kepala sekolah sangat penting dalam mengembangkan dan meningkatkan kemampuan profesionalitas guru dalam pembelajaran, hal itu terbukti dari data aspek kompetensi profesionalitas guru dapat dilihat pada penguasaan materi didapat skor berjumlah 3 dengan kategori tinggi, selanjutnya untuk indikator kemampuan membuka pelajaran didapat skor 4 dengan kategori sangat tinggi, pada kemampuan bertanya didapat skor 3 dengan kategori tinggi, pada kemampuan mengadakan variasi pembelajaran didapat skor berjumlah 4 dengan kategori sangat tinggi, pada kejelasan penyajian materi didapat skor berjumlah 3 dengan kategori tinggi, dan pada kemampuan mengelola kelas didapat skor berjumlah 3 dengan kategori tinggi. Dapat disimpulkan bahwa kemampuan profesionalitas guru dapat meningkat dengan adanya upaya perbaikan pembelajaran oleh kepala Sekolah.
\end{abstract}

Kata Kunci: kepala sekolah, kemampuan profesionalitas guru

\section{THE PRINCIPAL'S ROLE ON TEACHERS‘ PROFESSIONAL ABILITY IN THE TEACHING PROCESS AT SDN 22 BENGKALIS}

\begin{abstract}
This research was school action aiming to improve the school quality and the teachers' performance. This research was conducted at SDN $22 X$. The subjects in this study were the teachers who taught at the school. This research utilized a descriptive quantitative method that explained and described the facts found at the time of the research. The main purpose of this research was to improve and develop the teachers' ability or professional competence in teaching to create good learning conditions, to produce good learning outcomes, and to improve the quality of education. Based on the results of the study, it was seen that the principal's role was very crucial in developing and improving the teacher's professional ability in teaching. It was supported by the data showing that the score of teachers' mastery on the materials was 3 with "high" category. Then, the score of the ability to open lessons was 4 with "very high" category. After that, the score of the ability to ask questions was 3 with "high" category while the score of the ability to hold learning variations was 4 with "very high" category. Moreover, the score of the clarity of presenting the material was 3 with "high" category, and the score of the ability to manage the class was 4 with "very high" category. Thus, this research concluded that teacers' professional ability increased as the result of the principal's efforts to improve teaching process.
\end{abstract}

Keywords: principal, teacher professionalism ability

\begin{tabular}{|c|c|c|}
\hline Submitted & Accepted & Published \\
\hline 21 Oktober 2021 & 06 November 2021 & 27 November 2021 \\
\hline
\end{tabular}

\begin{tabular}{|l|l|l|l|}
\hline Citation & $:$ & $\begin{array}{r}\text { Anas, A. (2021). Peran Kepala Sekolah Terhadap Peningkatan Kompetensi Profesionalitas Guru Pada Proses } \\
\text { Pembelajaran Di Sdn 22 Bengkalis. Jurnal PAJAR (Pendidikan dan Pengajaran), 5(6), 1753-1759. DOI : } \\
\text { http://dx.doi.org/10.33578/pjr.v5i6.8591. }\end{array}$ \\
\hline
\end{tabular}

\section{PENDAHULUAN}

Kepemimpinan merupakan salah satu bagian dari proses manajemen. Kepemimpinan memerlukan perhatian yang utama, karena melalui kepemimpinan diharapkan akan lahir tenagatenaga berkualitas dalam berbagai bidang yang pada akhirnya dapat meningkatkan sumber daya manusia yang berkualitas. Menurut Soepardi yang dikutip oleh Mulyasa (2003) kepemimpinan adalah kemampuan untuk menggerakkan, mempengaruhi, memotivasi, mengajak, mengarahkan, menasehati, membimbing, menyuruh, memerintah, melarang, serta membina 
dengan maksud agar manusia sebagai media manajemen mau bekerja dalam rangka mencapai tujuan administrasi secara efektif dan efisien. Pimpinan tertinggi disebuah lembaga pendidikan adalah kepala sekolah. Kedudukan kepala sekolah sangatlah penting. Sebagaimana yang diungkapkan oleh Fattah (2013), kepala sekolah merupakan kunci kesuksesan sekolah dalam mengadakan perubahan. Kepala sekolah juga disebut sebagai the key person (penanggungjawab utama atau faktor kunci) dalam menggerakkan potensi sekolah dan mempunyai otoritas penuh dalam mengelola sekolah termasuk melakukan pengelolaan dan pengembangan profesionalisme guru.

Guru merupakan salah satu faktor penentu tinggi rendahnya mutu pendidikan. Dengan kata lain, untuk meningkatkan mutu pendidikan dibutuhkan guru yang profesional. Sebagai pendidik profesional, guru mempunyai tugas utama mendidik, mengajar, membimbing, mengarahkan, melatih, menilai, dan mengevaluasi peserta didik pada pendidikan anak usia dini jalur pendidikan formal, pendidikan dasar, dan pendidikan menengah. Keberadaan guru sebagai salah satu komponen dalam sistem pendidikan nasional, dianggap sangat penting, terutama bagi suatu bangsa yang sedang membangun, seperti Indonesia. Dengan adanya guru, segenap ilmu pengetahuan, keterampilan serta nilai-nilai moral diberikan pada peserta didik melalui proses mengajar, melatih dan mendidik. Tentu dengan harapan agar kelak dapat bermanfaat bagi peserta didik dalam menjalani kehidupan.

Peran guru sangat dominan dalam menentukan perubahan suatu bangsa. Bahkan masyarakat menempatkan guru pada tempat yang lebih terhormat dilingkungannya karena dari tangan seorang guru diharapkan manusia dapat menjadi manusia dewasa yang bermanfaat dalam kehidupan bermasyarakat(Suprihatin, 2013). Idealnya, sosok guru ketika berada di depan memberi suri tauladan, ketika berada di tengahtengah memberikan ide yang membangun, dan ketika berada di belakang memberi dorongan dan arahan pada peserta didik. Keberhasilan pendidikan ditentukan oleh banyak faktor, salah satunya faktor guru yang profesional. saat ini, profesionalisme bagi guru merupakan sebuah keharusan. Akan tetapi, ketidakberhasilan peserta didik selalu disangkutpautkan dengan kinerja guru yang belum baik. hal ini seolah menandakan bahwa masyarakat percaya bahwa seorang guru telah profesional apabila peserta didik berhasil pula, profesi guru dalam mengajar membutuhkan pengembangan. Kenyataan menunjukkan bahwa kemajuan sekolah sangat ditentukan oleh pengembangan profesi guru. Seperti, yang selama ini selalu terjadi, ketika ada siswa yang tidak lulus Ujian Nasional, maka orang pertama yang disalahkan adalah guru.

Permasalahan di sekolah dasar adalah rendahnya kualitas pendidikan. Hal ini dapat diketahui dari hasil ujian prestasi belajar murid atau tingkat penguasaan murid terhadap materi pelajaran yang tergolong rendah. Prestasi belajar murid sebagai salah satu indikator kualitas pendidikan dipengaruhi oleh berbagai komponen. Komponen-komponen dimaksud menurutu Rohiat (2008) adalah (1) siswa; (2) guru sebagai tenaga pendidik; (3) administrasi; (4) kurikulum; (5) keuangan; (6) sarana dan prasarana sebagai instrumental; (7) politik; (8) ekonomi; (9) sosialbudaya; dan (10) kependudukan. Setiap komponen tersebut saling berinteraksi selama proses pelaksanaan pendidikan berlangsung, untuk menghasilkan perubahan perilaku para siswa. Berdasarkan dari isu yang ditemukan dikalangan masyarakat, kepala sekolah sebagai seorang supervisor memiliki kewajiban untuk melaksanakan pengawasan terhadap guru terutama dalam melaksanakan pembelajaran di kelas. Dalam hal ini kepala sekolah wajib untuk melakukan pengawasan terhadap guru misalnya melalui observasi kelas dan kunjungan kelas. Mengingat guru juga seorang manusia, yang mungkin pada saat mengajar masih memerlukan bimbingan dari seorang kepala sekolah. Sehingga, adanya proses supervisi oleh kepala sekolah akan dapat diketahui apa saja yang sudah baik, dan apa saja yang masih perlu diperbaiki oleh guru dalam melaksanakan kegiatan belajar mengajar. Menurut Sutrisno (2017) upaya untuk meningkatkan kompetensi profesional seorang guru adalah keharusan. Perlu disadari bahwa upaya tersebut bukanlah tugas guru saja, akan tetapi juga ada peran kepala sekolah sebagai manajer sumber daya manusia di sekolah untuk membuat kegiatan 
dan pelatihan yang bermaksud meningkatkan wawasan guru, keterampilan guru, dan memperbaiki sikap guru dalam proses pembelajaran. Kepala sekolah sebagai leader harus dapat memotivasi guru untuk tetap konsisten meningkatkan kompetensi profesionalnya.

Menurut Mulyasa (2013) Salah satu dari kompetensi yang harus dimiliki guru adalah kompetensi profesional, di dalam Undang-Undang Nomor 14 Tahun 2005 dijelaskan bahwa kompetensi profesional ialah suatu kesanggupan seorang guru dalam menguasai materi pelajaran secara luas dan mendalam. Atau dengan kata lain dapat dikatakan bahwa kompetensi profesional ialah suatu kemampuan yang dimiliki oleh seorang guru untuk memahami dan menguasai materi pembelajaran yang menjadi tanggung jawabnya secara utuh, mendalam dan luas. Oleh karena itu perlu adanya tindakan yang dilakukan oleh pemimpin dalam hal ini kepala sekolah dengan melakukan pendampingan, pengawasan, pengembangan, dan pelatihan-pelatihan yang bertujuan untuk meningkatkan kemampuan guru tersebut.

\section{METODE PENELITIAN}

Penelitian ini berupa penelitian tindakan sekolah yang dilakukan oleh kepala Sekolah. Penelitian ini memiliki tujuan untuk memperbaiki mutu pendidikan serta meningkatkan kemampuan guru dalam kegiatan pembelajaran (Ali Imron, 2008). Penelitian ini dilakukan di SDN $22 \mathrm{X}$, subjek dalam penelitian ini adalah guru-guru yang mengajar di Sekolah tersebut. Metode penelitian menggunakan deskriptif kuantitatif, yang mana metode ini bertujuan menjelaskan secara faktual apa yang terjadi dan ditemukan dalam penelitian tersebut. Penelitian ini terdiri dari 2 siklus, tahapan-tahapan yang dilalui dalam penelitian tindakan kelas yaitu perencanaan/persiapan tindakan, pelaksanaan tindakan, observasi, dan refleksi. Instrument dalam penelitian ini adalah menggunakan lembar observasi untuk melihat aktivitas guru pada saat kegiatan pembelajaran dan angket. Angket merupakan wawancara tidak langsung dari peneliti kepada sumber informasi atau berupa beberapa pertanyaan yang dapat mewakili peneliti. Untuk menghitung skor penilaian indikator kemampuan profesionalitas guru dalam mengajar dapat dilihat pada tabel 1:

\section{Tabel 1. Indikator kompetensi profesionalitas guru}

\begin{tabular}{|c|c|c|c|c|c|}
\hline \multirow[t]{2}{*}{ No } & \multirow[t]{2}{*}{ Indikator } & \multicolumn{4}{|c|}{ Skor Penilaian } \\
\hline & & 1 & 2 & 3 & 4 \\
\hline 1. & Penguasaan Materi & & & & \\
\hline 2. & $\begin{array}{l}\text { Kemampuan membuka } \\
\text { pelajaran }\end{array}$ & & & & \\
\hline 3. & Kemampuan bertanya & & & & \\
\hline 4. & $\begin{array}{l}\text { Kemampuan mengadakan } \\
\text { variasi pembelajaran }\end{array}$ & & & & \\
\hline 5. & $\begin{array}{l}\text { Kejelasan dan penyajian } \\
\text { materi }\end{array}$ & & & & \\
\hline 6. & $\begin{array}{l}\text { Kemampuan mengelola } \\
\text { kelas }\end{array}$ & & & & \\
\hline
\end{tabular}

Keterangan:

Sangat Tinggi $=4$

Tinggi $=3$

Sedang $\quad=2$

Rendah $\quad=1$
Kemudian untuk menghitung data aktivitas guru dalam pembelajaran dapat dihitung dengan menggunakan rumus berikut:

Keterangan :

$p=\frac{\mathrm{f}}{\mathrm{n}} \times 100 \%$

(Anas Sudjono, 2004) 
Keterangan:

$\mathrm{f} \quad=$ Frekuensi yang sedang dicari

$\mathrm{n} \quad=\quad$ Number of Cases (jumlah

persentasenya

frekuensi/banyaknya individu)

$\mathrm{P} \quad=$ Angka persentase

$100 \%=$ Bilangan Tetap

Tabel 2. Analisis Hasil Observasi Kegiatan Guru

\begin{tabular}{cc}
\hline Interval rata-rata skor (\%) & Kategori \\
\hline $76-100$ & Sangat Tinggi \\
$51-75$ & Tinggi \\
$26-50$ & Sedang \\
$0-25$ & Rendah \\
\hline
\end{tabular}

Sumber : Dimodifikasi dari (Sugiyono, 2015)

\section{HASIL DAN PEMBAHASAN}

Kompetensi profesionalitas guru dalam mengajar sangat berpengaruh dalam terwujudnya tujuan utama dari pembelajaran yaitu meningkatnya mutu pendidikan dan meningkatnya hasil belajar siswa, karena kompetensi profesionalitas guru dapat meliputi penguasaan materi, kemampuan membuka pelajaran dengan baik, kemampuan bertanya, kemampuan menerapkan metode atau variasi pembelajaran terbaru, kemampuan dalam penyampaian atau penyajian materi pembelajaran, dan kemampuan mengelola kelas yang dapat membangun suasana yang komunikatif antara guru dan siswa. Berikut adalah datahasil analisis kemampuan profesionalitas guru dalam mengajar pada siklus I:

Tabel 3. Indikator Kompetensi Profesionalitas Guru Siklus I

\begin{tabular}{|c|c|c|c|c|c|}
\hline \multirow[t]{2}{*}{$\mathbf{N}$} & \multirow[t]{2}{*}{ Indikator } & \multicolumn{4}{|c|}{ Skor Penilaian } \\
\hline & & 1 & 2 & 3 & 4 \\
\hline 1. & Penguasaan Materi & & & & \\
\hline 2. & $\begin{array}{l}\text { Kemampuan membuka } \\
\text { pelajaran }\end{array}$ & & & & \\
\hline 3. & Kemampuan bertanya & & & & \\
\hline 4. & $\begin{array}{l}\text { Kemampuan mengadakan } \sqrt{ } \\
\text { variasi pembelajaran }\end{array}$ & & & & \\
\hline 5. & $\begin{array}{l}\text { Kejelasan dan penyajian } \quad \sqrt{ } \\
\text { materi }\end{array}$ & & & & \\
\hline 6. & $\begin{array}{l}\text { Kemampuan mengelola } \\
\text { kelas }\end{array}$ & & & & \\
\hline
\end{tabular}

Berdasarkan tabel 3 diatas dapat dilihat bahwa data analisis kompetensi profesionalitas guru dalam pembelajaran pada siklus I ditemukan pada indikator penguasaan materi didapat skor berjumlah 2 dengan kategori sedang, selanjutnya untuk indikator kemampuan membuka pelajaran didapat skor 2 dengan kategori sedang, pada kemampuan bertanya didapat skor 2 dengan kategori sedang, pada kemampuan mengadakan variasi pembelajaran didapat skor berjumlah 1 dengan kategori rendah, pada kejelasan penyajian materi didapat skor berjumlah 1 dengan kategori rendah, dan pada kemampuan mengelola kelas didapat skor berjumlah 2 dengan kategori sedang.

Kemudian setelah dilakukan refleksi pembelajaran atau upaya perbaikan pembelajaran oleh kepala sekolah pada siklus II penelitian, terjadi peningkatan kompetensi profesionalitas guru. Dapat dilihat pada tabel berikut: 
Jurnal PAJAR (Pendidikan dan Pengajaran)

Volume 5 Nomor 6 November | ISSN Cetak : 2580 - 8435| | ISSN Online : 2614 - 1337

DOI : http://dx.doi.org/10.33578/pjr.v5i6.8591

Tabel 4. Indikator kompetensi profesionalitas guru siklus II

\begin{tabular}{|c|c|c|c|c|c|}
\hline \multirow[t]{2}{*}{ No } & \multirow[t]{2}{*}{ Indikator } & \multicolumn{4}{|c|}{ Skor Penilaian } \\
\hline & & 1 & 2 & 3 & 4 \\
\hline 1. & Penguasaan Materi & & & & \\
\hline 2. & $\begin{array}{l}\text { Kemampuan membuka } \\
\text { pelajaran }\end{array}$ & & & & \\
\hline 3. & Kemampuan bertanya & & & & \\
\hline 4. & $\begin{array}{l}\text { Kemampuan mengadakan } \\
\text { variasi pembelajaran }\end{array}$ & & & & \\
\hline 5. & $\begin{array}{l}\text { Kejelasan dan penyajian } \\
\text { materi }\end{array}$ & & & & \\
\hline 6. & $\begin{array}{l}\text { Kemampuan mengelola } \\
\text { kelas }\end{array}$ & & & & \\
\hline
\end{tabular}

Berdasarkan tabel diatas dapat dilihat bahwa data analisis kompetensi profesionalitas guru dalam pembelajaran pada siklus II ditemukan pada indikator penguasaan materi didapat skor berjumlah 3 dengan kategori tinggi, selanjutnya untuk indikator kemampuan membuka pelajaran didapat skor 4 dengan kategori sangat tinggi, pada kemampuan bertanya didapat skor 3 dengan kategori tinggi, pada kemampuan mengadakan variasi pembelajaran didapat skor berjumlah 4 dengan kategori sangat tinggi, pada kejelasan penyajian materi didapat skor berjumlah 3 dengan kategori tinggi, dan pada kemampuan mengelola kelas didapat skor berjumlah 3 dengan kategori tinggi.

Untuk melihat data hasil analisis aktivitas guru pada saat pembelajaran yang terdiri dari 2 siklus dapat dilihat pada tabel berikut:

Tabel 5. Persentase aktivitas guru siklus I dan siklus II

\begin{tabular}{llll}
\hline Siklus & Pertemuan & Persentase & kategori \\
\hline I & I & $51 \%$ & Cukup baik \\
& II & $62 \%$ & Cukup baik \\
II & III & $82 \%$ & Baik \\
& IV & $88 \%$ & Baik \\
\hline
\end{tabular}

Pada tabel diatas dapat dilihat persentase aktivitas guru pada siklus I pertemuan pertama didapat persentase sebesar $51 \%$ dengan kategori cukup baik, kemudian pada pertemuan kedua didapat persentase sebesar $62 \%$ dengan kategori cukup baik, selanjutnya pada siklus II pertemuan ketiga didapat persentase sebesar $82 \%$ dengan kategori baik, dan pada pertemuan keempat didapat persentase $88 \%$. Terjadi peningkatan yang cukup baik pada aktivitas guru setelah dilakukan refleksi pembelajaran oleh kepala Sekolah.

\section{Pembahasan}

Upaya pembinaan dan pengembangan profesionalisme guru secara eksternal telah banyak dilakukan, terutama melalui berbagai kegiatan penataran dan latihan. Akan tetapi, upaya-upaya tersebut kurang memberi efek terhadap mutu pendidikan. Hal ini disebabkan banyak guru yang mengikuti penataran dan latihan itu bukan karena motivasi dari dirinya sendiri, melainkan karena ditugaskan atau diwajibkan oleh atasannya.

Dalam rangka meningkatkan kemampuan mengajar guru agar dapat menyesuaikan diri dengan perkembangan ilmu pengtahuan dan kemajuan teknologi yang semakin pesat, maka perlu dilakukan pengembangan profesionalisme guru (Sedarmayanti, 2016). Menurut Wahjosumidjo (2005) pengembangan profesionalisme dimaksudkan untuk memperluas pengetahuan dan meningkatkan keterampilan mengajar guru. Hal tersebut dapat dilakukan melalui berbagai kegiatan, baik yang diupayakan oleh guru-guru sendiri maupun yang diupayakan 
oleh pimpinannya (kepala sekolah). Kepala Sekolah memiliki peran yang sangat penting dalam mengembangkan kemampuan profesionalitas guru, karena kepala sekolah sebagai pemimpin memiliki wewenang terhadap para guru agar dapat mencapai serta meningkatkan mutu pendidikan terutama di Sekolah yang dipimpinnya.

Berdasarkan dari hasil penelitian dapat dilihat peran kepala sekolah terhadap peningkatan kemampuan profesionalitas guru sangatlah penting hal itu terbukti dari hasil penelitian bahwa peran kepala sekolah terhadap kemampuan guru berdampak baik pada berbagai sektor atau aspek kompetensi profesionalitas guru dapat dilihat pada penguasaan materi didapat skor berjumlah 3 dengan kategori tinggi, selanjutnya untuk indikator kemampuan membuka pelajaran didapat skor 4 dengan kategori sangat tinggi, pada kemampuan bertanya didapat skor 3 dengan kategori tinggi, pada kemampuan mengadakan variasi pembelajaran didapat skor berjumlah 4 dengan kategori sangat tinggi, pada kejelasan penyajian materi didapat skor berjumlah 3 dengan kategori tinggi, dan pada kemampuan mengelola kelas didapat skor berjumlah 3 dengan kategori tinggi. Untuk data persentase aktivitas guru pada siklus I pertemuan pertama didapat persentase sebesar $51 \%$ dengan kategori cukup baik, kemudian pada pertemuan kedua didapat persentase sebesar $62 \%$ dengan kategori cukup baik, selanjutnya pada siklus II pertemuan ketiga didapat persentase sebesar $82 \%$ dengan kategori baik, dan pada pertemuan keempat didapat persentase $88 \%$. Terjadi peningkatan yang cukup baik pada aktivitas guru setelah dilakukan refleksi pembelajaran oleh kepala Sekolah.

Dapat disimpulkan bahwa peran kepala sekolah sangat penting dalam meningkatkan kemampuan profesionalitas guru, hal itu dikarenaka kepala sekolah sebagai pemimpin di sekolahnya dapat melakukan berbagai tindakan berupa supervise, pemberian pelatihan, membuat ketetapan-ketetapan di sekolah yang dapat meningkatkan kinerja dan disiplin guru, dan berbagai tindakan lainnya. Hasil penelitian lain yang sejalan dengan penelitian ini juga menunjukkan peran kepala sekolah sangat penting bagi kemampuan serta kinerja guru dalam pembelajaran, karena kepala sekolah sebagai pemimpin di Sekolah tersebut dapat langsung melihat kondisi guru-guru (Mayasari, dkk, 2018). Mengenai hal itu sejalan dengan pendapat Karwati (2013) mengatakan bahwa melalui supervise dari kepala Sekolah dapat meningkatkan kemampuan guru dalam mengajar karena guru juga perlu pendampingan dari pemimpinnya agar tetap berada pada ketentuan yang sudah ditetapkan.

\section{SIMPULAN DAN REKOMENDASI}

Berdasarkan hasil penelitian dan pembahasan dapat disimpulkan bahwa peran kepala sekolah terhadap kemampuan profesionalitas guru sangat penting, hal itu berdampak pada meningkatnya kemampuan profesionalitas guru dan dapat meningkatkan aktivitas guru pada proses pembelajaran. terbukti dari data hasil penelitian pada aspek kompetensi profesionalitas guru dapat dilihat pada penguasaan materi didapat skor berjumlah 3 dengan kategori tinggi, selanjutnya untuk indikator kemampuan membuka pelajaran didapat skor 4 dengan kategori sangat tinggi, pada kemampuan bertanya didapat skor 3 dengan kategori tinggi, pada kemampuan mengadakan variasi pembelajaran didapat skor berjumlah 4 dengan kategori sangat tinggi, pada kejelasan penyajian materi didapat skor berjumlah 3 dengan kategori tinggi, dan pada kemampuan mengelola kelas didapat skor berjumlah 3 dengan kategori tinggi.

\section{DAFTAR PUSTAKA}

Fattah, N. (2013). Landasan Manajemen Pendidikan, Bandung: PT Remaja Rosdakarya.

Imron, A. (2008). Penelitian tindakan sekolah bagi pengawas dalam rangka peningkatan mutu pendidikan. Jurnal Tenaga Kependidikan Edisi Nomor 2 tahun 2008. Jakarta: Direktorat Tendik, Ditjen Mutendik, Depdiknas.

Karwati. (2013). Kinerja dan Profesionalisme Kepala Sekolah Membangun Sekolah yang Bermutu. Bandung: Alfabeta

Mayasari, E., \& Syarif, M. (2018). Strategi Kepala Sekolah dalam Meningkatkan Kompetensi Guru Terhadap Hasil Belajar Siswa di SMA Negeri 1 Peukan Bada Aceh Besar. 
Jurnal PAJAR (Pendidikan dan Pengajaran)

Volume 5 Nomor 6 November | ISSN Cetak : 2580 - 8435| ISSN Online : 2614 - 1337

DOI : http://dx.doi.org/10.33578/pjr.v5i6.8591

Fitrah. Jurnal Kajian Ilmu-ilmu

Keislaman, 04 (1), 141-164

Mulyasa. (2003). Menjadi Kepala Sekolah

Profesional Dalam Konteks Menyukseskan $M B S$ dan KBK, Bandung: PT. Remaja Rosdakarya.

Mulyasa. (2013). Uji Kompetensi dan Penilaian

Kinerja Guru. Bandung: Remaja Rosdakarya.

Rohiat. (2008). Manajemen Sekolah. Bandung: Refika Aditama.

Sugiyono. (2015). Metode Penelitian Pendidikan. Bandung: Alfabeta.

Suprihatin. (2013). Guru Profesional. Yogyakarta: Ar-Ruzz Media.

Sutrisno, E. (2017). Manajemen Sumber Daya Manusia (Ke-9). Jakarta: Kencana

Sedarmayanti. (2016). Manajemen Sumber Daya Manusia Reformasi Birokrasi dan Manajemen Pegawai Negeri Sipil. Bandung: PT Refika Aditama.

Wahjosumidjo. (2005). Kepemimpinan Kepala Sekolah: Tinjauan Teoritik Dan Permasalahannya. Jakarta: Raja Grapindo Persada. 